\title{
Red blood cell abnormalities in cardiac valvular disease
}

\author{
J. FORSHAW AND L. HARWOOD \\ Sefton General Hospital, Liverpool
}

SYNOPSIS Nineteen patients with morphological abnormalities of the red blood cells are described, and these formed approximately $3 \%$ of the total cases of cardiac valvular disease. In two patients ${ }^{\circ}$ the abnormal blood film developed after the insertion of an aortic and mitral valve prosthesis $\infty^{\circ}$ respectively, but in another two patients the abnormal blood film was corrected by aortic valve $\stackrel{\infty}{\infty}$

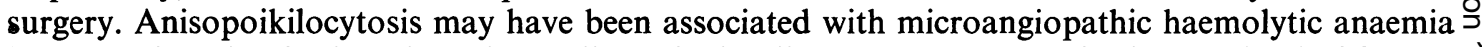
in one patient, but in the others the cardiac valvular disease was severe and other mechanical factors were not present. The mitral valve was involved in 16 patients and the aortic valve in eight.

Elliptocytosis was the only abnormality in 11 blood films, schistocytes and burr cells were present $\stackrel{\Phi}{乛}$ in seven, and in three there were a few microspherocytes. Family studies in seven patients produced evidence of hereditary elliptocytosis in three.

Anaemia was present in only two patients. One of these had infective endocarditis, and the other $\overrightarrow{\mathscr{Q}}$ developed overt haemolytic anaemia following the replacement of a diseased mitral valve by a. Starr-Edwards prosthesis. In this latter case there was a transiently positive direct antiglobulin test, and the anaemia and abnormal blood picture were corrected without further surgical treatment. Haemolytic anaemia did not develop in 23 patients after the insertion of an aortic valve prosthesis or homograft.

Indirect evidence of haemolysis was obtained in some patients who were not anaemic. There was a reticulocytosis in one third and serum haptoglobins were decreased or absent in over half of the patients tested.

The development of haemolytic anaemia and gross deformities of the red blood cells following open heart surgery was first observed in 1954 (Rose, Hufnagel, Freis, Harvey, and Partenope, 1954). Since then a number of similar cases have been reported, and recently Cooley (1966) reviewed 28 cases in which haemolytic anaemia occurred after intracardiac prosthetic surgery. An aortic valve replacement had been performed in 15 of these, a repair of a septal defect in nine, a mitral valve replacement in two, and both a mitral and aortic valve replacement in one; complete haematological recovery occurred in only three cases, spontaneously in one case and following successful replacement of a defective aortic valve prosthesis in the other two.

It has been assumed that in most instances a jet stream of blood resulted from separation or tearing of the valve prosthesis, and that the haemolysis was due to mechanical trauma (Pirofsky, 1966). HowReceived for publication 6 April 1967. ever, progressive valve damage may also cause severe $\dot{0}$ turbulence of the blood, and recently there have been 3 . several single case reports of mechanical haemolytic $\delta$ anaemia occurring in patients with severe aortic and $₹$ mitral valve disease who had not been treated by 윽 prosthetic surgery (Miller, Mengel, Kremer, Gutter- $D$ man, and Sinnegan, 1966; Westring, 1966; Ziper- 을 ovich and Paley, 1966). Studies on non-anaemic N patients with cardiac valvular disease have shown no ${ }^{\mathcal{N}}$ morphological abnormality of the red blood cells $\tilde{O}$ (Miller et al., 1966; Westring, 1966). However, the $\underset{\omega}{N}$ survival of the red blood cells was shortened in 18 o out of 21 non-anaemic patients with aortic valvular disease, no reference being made to the appearance $\frac{\vec{D}}{\mathbb{D}}$ of the blood films (Brodeur, Sutherland, Koler, $\stackrel{+}{+}$ Starr, Kimsey, and Griswold, 1965).

Haemolytic anaemia may not always be caused solely by mechanical trauma, and an autoimmune $\stackrel{\mathbb{D}}{\circ}$ response was thought to exist in seven patients, in $\mathbb{\otimes}$ whom haemolysis followed the insertion of a Starr- 
Edwards aortic valve prosthesis, and in six of whom the direct anti-globulin (Coombs) test became positive (Pirofsky, Sutherland, Starr, and Griswold, 1965). A positive direct Coombs test was also reported by Brodeur et al. (1965) in one of their patients with aortic valve disease who had not been treated by cardiac surgery.

Three cases of haemolytic anaemia complicating cardiac surgery have been reported from the Hammersmith Hospital (Sayed, Dacie, Handley, Lewis, and Cleland, 1961; Marsh, 1964) but most of the observations on damage to the red blood cells caused by cardiac valvular disease have been made in the U.S.A. At Sefton General Hospital, which includes the Liverpool Regional Cardiac Centre, we have examined blood films from a large number of patients with cardiac valvular disease, and over three years ago we gained the impression that there was an increased incidence of deformities of the red blood cells in these patients. In the present paper we describe 19 patients with cardiac valvular disease in whom abnormally shaped red blood cells were prominent.

\section{CLINICAL MATERIAL AND METHODS}

During a period of three years a prospective study was made of all cases in which the blood film showed striking abnormalities of the red blood cells. These changes consisted essentially of elliptocytosis, crenation with burr cell production, irregularly shaped red blood cell fragments (schistocytes), and microspherocytes. The abnormal appearance of the cells was confirmed by examining at least three blood films obtained by finger prick. Usually the diagnosis was not known when the blood film was first examined, and cases in which the diagnosis subsequently turned out to be uraemia, carcinoma, or a primary haematological disease were then excluded.

There remained a total of 40 patients. Nineteen of these had cardiac valvular disease, seven had congestive cardiac failure due to non-valvular cardiac disease, four had miscellaneous disorders (brucellosis, infectious mononucleosis, thyrotoxicosis, chronic alcoholism) and in 10 a diagnosis was not made. During this three-year period blood films from approximately 600 patients with cardiac valvular disease were examined, and these included 24 patients in whom a damaged valve had been repaired by insertion of a homograft or prosthesis.

Conventional haematological techniques were used (Dacie and Lewis, 1963). Serum haptoglobins were measured qualitatively by a modification of Schumm's reaction (Neale, Aber, and Northam, 1958).

\section{RESULTS}

CLINICAL DETAILS The clinical details of the patients with cardiac valvular disease are shown in Table $I$. There were 12 women and seven men. In one patient (no. 10) there was no clinical evidence of cardiac valvular disease but post-mortem examination revealed the vegetations of infective endocarditis on rheumatic mitral and aortic valves, and also multiple embolic infarcts in the brain, kidneys, and spleen. In the other patients there was a long history of symptoms of cardiac failure, and atrial fibrillation was present in 13 . The valvular disease was con-

TABLE I

CLINICAL DETAILS

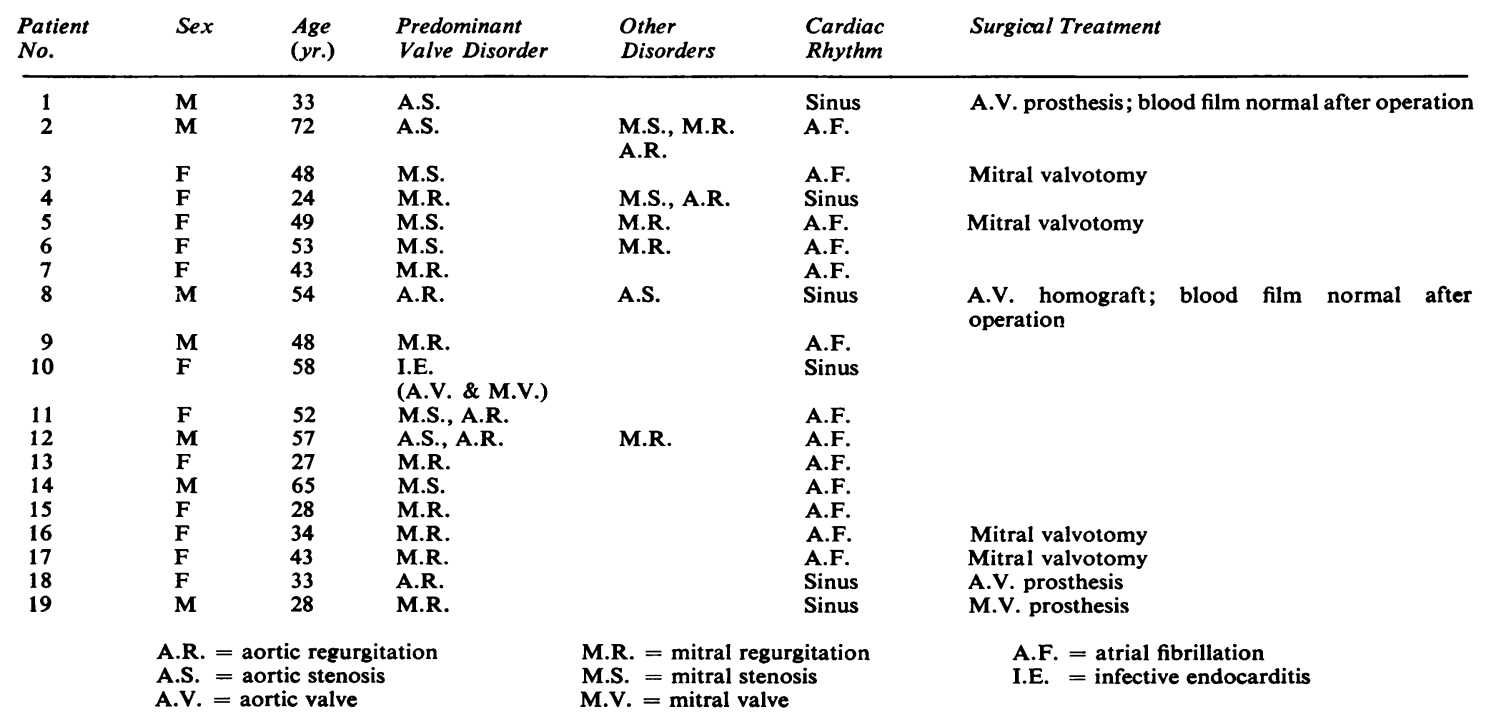


sidered to be congenital in one patient (no. 1) and rheumatic in the others. The mitral valve alone was involved in 11 patients, the aortic valve alone in three, and both valves in five. The predominant valvular disorders were mitral regurgitation in seven patients, mitral stenosis in four, aortic stenosis in two, aortic regurgitation in one, combined mitral stenosis and aortic regurgitation in one, and combined aortic stenosis and aortic regurgitation in one. In the other two patients (nos. 18 and 19) the abnormal blood films only developed after the replacement of the aortic and mitral valves respectively by a Starr-Edwards prosthesis. A mitral valvotomy had been performed in four patients (nos. 3, 5, 16, 17); in three of these we had not examined the blood film before the operation but in the other (no. 5) the film was abnormal both before and after the operation. In two patients (nos. 1 and
8) the blood film became normal after the replacement of the aortic valve by a Starr-Edwards prosthesis and a homograft respectively.

HAEMATOLOGICAL DETAILS The data are summarized in Table II. Elliptocytosis was present in all but one of the blood films, and was the only abnormality in 11. Schistocytes and burr cells were present in seven of the blood films, and in three there were a few microspherocytes.

The haemoglobin level was below 11 g. per $100 \mathrm{ml}$. in only two patients: one of these (no. 10) had infective endocarditis with multiple emboli, and the other (no. 19), who is described in detail below, developed overt haemolytic anaemia following the insertion of a Starr-Edwards prosthesis. The platelet count was always normal, but there was a leucocytosis in four patients. Reticulocytes were above

TABLE II

HAEMATOLOGICAL DETAILS

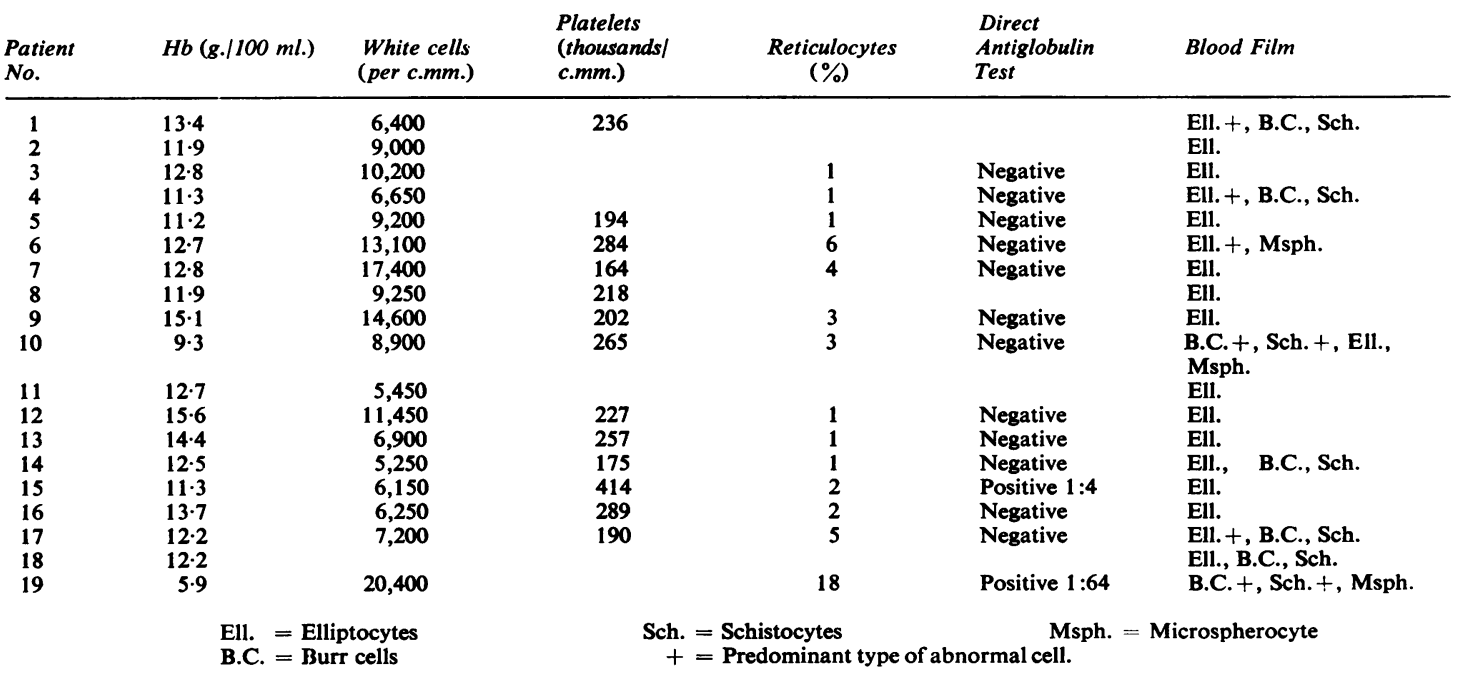

TABLE III

RESULTS OF TESTS FOR HAEMOLYSIS AND FOR OSMOTIC FRAGILITY OF RED BLOOD CELLS

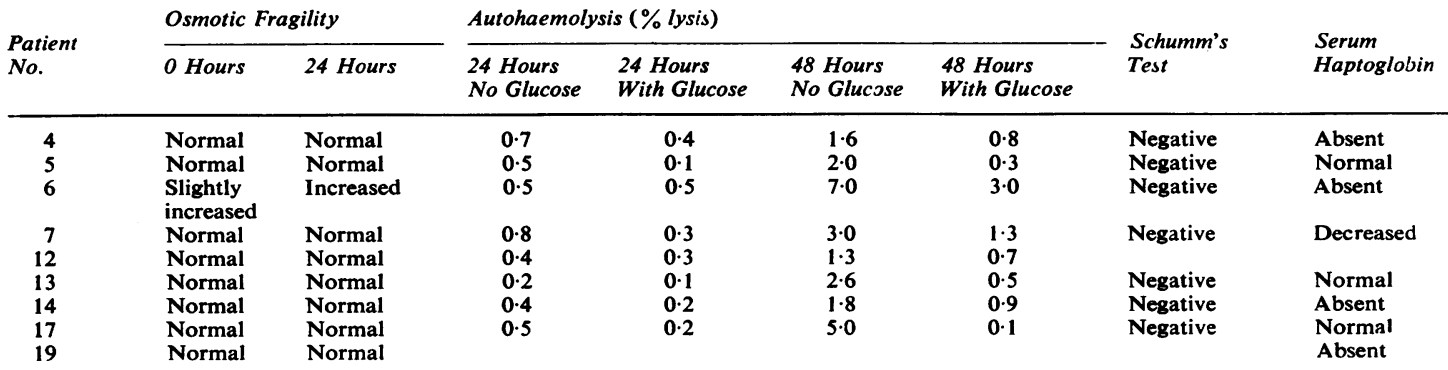


$2 \%$ in six, and the direct Coombs test was positive in two out of 14 patients. One of the Coombs tests showed a weakly positive reaction up to a titre of $1: 4$, and the other a moderately strong reaction up to a titre of $1: 64$.

The results of the tests for haemolysis and osmotic fragility of the red blood cells are shown in Table III. The osmotic fragility was increased in one of the nine patients tested. Autohaemolysis was increased after 48 hours' incubation of the red blood cells in the same patient, but it was within the normal range in the other patients. Schumm's test for methaemalbumin in the serum was negative in seven patients, but the serum haptoglobins were decreased or absent in five out of eight patients.

The red blood cells were normochromic in every case. However, in order to check that iron deficiency was not a contributory factor in producing the elliptocytosis, the serum iron level and total ironbinding capacity were estimated in five patients (nos. 2, 4, 6, 7, and 12). Iron deficiency was present in one of these (no. 2), but the elliptocytosis persisted after iron treatment had been given.

Blood films from the available members of the families of seven patients were examined, and elliptocytosis was discovered in three families. Details of these family studies are shown in Table IV.

\section{TABLE IV}

\section{RESULTS OF FAMILY STUDIES FOR ELLIPTOCYTOSIS}

\begin{tabular}{|c|c|c|}
\hline \multirow{2}{*}{$\begin{array}{l}\text { Patient } \\
\text { No. }\end{array}$} & \multicolumn{2}{|l|}{ Results } \\
\hline & Positive & Negative \\
\hline 1 & \multirow{7}{*}{$\begin{array}{l}\text { Father } \\
\text { Two sisters, daughter } \\
\text { Daughter }\end{array}$} & Mother, sister, son \\
\hline 3 & & Daughter \\
\hline 4 & & Mother, daughter \\
\hline 5 & & \\
\hline 6 & & Son \\
\hline 7 & & $\begin{array}{l}\text { Father, mother, } \\
\text { brother, son }\end{array}$ \\
\hline 12 & & Two sisters, mother \\
\hline
\end{tabular}

\section{CASE REPORT}

This patient (no. 19) developed chorea in 1949 when he was 11 years old. Seven years later he first complained of dyspnoea, and the signs of mitral stenosis were observed then. Mitral valvotomy was carried out in 1958 and in 1961, and the haemoglobin level and blood film were noted to be normal, both before and after these two operations.

His cardiac condition gradually deteriorated, and in October 1966 it was decided to replace the damaged mitral valve with a Starr-Edwards prosthesis. Before the operation the haemoglobin was $14.8 \mathrm{~g}$. per $100 \mathrm{ml}$, the blood film normal, and no antibodies were detected in the serum when cross-matching with 10 pints of blood was carried out. These 10 pints of blood were transfused during the operation, which was performed by Mr. P. J.
Molloy at Broadgreen Hospital, and on the following day the haemoglobin was $11 \cdot 8 \mathrm{~g}$. per $100 \mathrm{ml}$.

Postoperative progress was satisfactory until the ninth day when the patient suddenly developed jaundice and haemoglobinuria. The haemoglobin level fell to $5.9 \mathrm{~g}$. per $100 \mathrm{ml}$., the reticulocytes rose to $18 \%$, and the blood film showed marked poikilocytosis with burr cells, schistocytes, and occasional microspherocytes. Red blood cell osmotic fragility and glucose 6-phosphate dehydrogenase activity were normal, and the direct Coombs, acid haemolysin, and Donath-Landsteiner tests were negative. Indirect Coombs test revealed an anti-Kell antibody in the serum. (The patient's cells were Kell negative.) The only drugs which the patient had been taking were aspirin and nitrazepam (Mogadon), but Heinz bodies were not demonstrated after incubating the red blood cells with both these drugs. There were no physical signs to suggest that the Starr-Edwards prosthesis had developed a mechanical defect.

He received three parenteral doses of 40 units A.C.T.H. and was transfused with 3 pints of blood. At the same time treatment was started with $20 \mathrm{mg}$. prednisone by mouth four times a day, and the dose was gradually reduced to $5 \mathrm{mg}$. twice daily. Four days later the haemoglobin was $10.4 \mathrm{~g}$. per $100 \mathrm{ml}$., the reticulocytes $10 \%$, the serum bilirubin $2.0 \mathrm{mg}$. per $100 \mathrm{ml}$., and there was an excess of urobilinogen in the urine. Serum haptoglobins were absent.

On the twenty-sixth postoperative day the haemoglobin was $12.6 \mathrm{~g}$. per $100 \mathrm{ml}$., reticulocytes $3 \%$, and the blood film normal. However, the direct Coombs test was now positive up to a titre of $1: 64$. Six days later the direct Coombs test was positive up to a titre of $1: 16$ and the reaction was much weaker. After another two days, both the direct and indirect Coombs tests were negative.

At the time of his discharge from hospital, 39 days after the operation, the haemoglobin was $12 \cdot 7 \mathrm{~g}$. per $100 \mathrm{ml}$., reticulocytes $5 \%$, and the blood film normal. Schumm's test was negative, but serum haptoglobins were still absent. He was feeling well and left hospital on treatment with $10 \mathrm{mg}$. prednisone daily. One month later the haemoglobin was $14.6 \mathrm{~g}$. per $100 \mathrm{ml}$. and the reticulocytes $2 \%$.

\section{DISCUSSION}

The role of mechanical factors in causing haemolysis and severe anisopoikilocytosis of the red blood cells has recently gained more prominence. Brain, Dacie, and Hourihane (1962) used the term 'microangiopathic haemolytic anaemia' to describe cases of renal disease and disseminated carcinoma in which mechanical destruction of the erythrocytes occurred during their passage through the narrowed lumen of diseased small blood vessels. We also reported the association of severe distortion of the red blood cells with renal failure and disseminated carcinoma (Forshaw and Harwood, 1966).

Our present observations have shown a significant, but less frequent, association between cardiac 
valvular disease and morphological abnormalities of the erythrocytes, these changes occurring in approximately $3 \%$ of cases. 'Microangiopathic haemolytic anaemia' may have been predominant in one case, in which functional disorder of the valves appeared to be slight, and there were friable vegetations on the aortic and mitral valves and widespread emboli. In the other 18 cases, however, the valvular disease was severe and other mechanical factors were not present.

In contrast to the blood picture in cases of renal failure and disseminated carcinoma, elliptocytosis was more often the prominent feature and burr cells and schistocytes were present less frequently. Family studies provided evidence of hereditary elliptocytosis in three out of seven patients, and a genetic cause was not entirely ruled out in the other four patients, as the family studies were not complete and the expression of the elliptocytic trait shows great variability (Weiss, 1963). On the other hand, mechanical trauma must have been the main aetiological factor in the two cases of elliptocytosis, in which the shape of the erythrocytes returned to normal after surgical treatment of aortic stenosis. It appears, therefore, that there is no single cause for the association between elliptocytosis and cardiac valvular disease. It may be that subjects with hereditary elliptocytosis are particularly liable to develop rheumatic fever, that mechanical trauma tends to increase the expression of the elliptocytic trait, or that there is a combination of these factors.

Seventeen of our patients were not anaemic. Morphological abnormalities of the red blood cells have not been reported previously in non-anaemic patients with cardiac valvular disease, although only a small number of such cases have been studied. Miller et al. (1966) and Westring (1966) investigated a total of 32 non-anaemic patients with severe valvular disease and found that all the blood films were normal. However, the incidence of abnormal blood films in our group of approximately 600 patients was only $3 \%$, and so the number of patients studied previously was insufficient to make an accurate assessment.

The results of erythrocyte survival studies in non-anaemic patients with aortic valvular disease have been conflicting, those obtained by Westring (1966) being invariably normal, and those by Brodeur et al. (1965) usually indicating decreased survival. We obtained indirect evidence of decreased survival of the erythrocytes in some of our patients, who were not anaemic. Increased osmotic fragility and autohaemolysis of the red blood cells were found in only one out of eight patients, but there was a reticulocytosis in one third and serum haptoglobins were decreased or absent in over half of the patients tested. Murray, Robinson, Dublin, Pitt, and Visnich (1966) found hypohaptoglobinaemia in $15.1 \%$ of patients who had had rheumatic fever, compared with only $3.8 \%$ of normal subjects, but they did not $\frac{\overline{\bar{N}}}{\overline{\mathrm{N}}}$ perform any other haematological investigations. They concluded that it was not clear whether the $\stackrel{\mathbb{Q}}{\Omega}$ hypohaptoglobinaemia was a consequence of rheum- $\%$ atic heart disease or an indicator of susceptibility to $\vec{\circ}$ rheumatic fever. However, it is significant that heart disease was present in all the patients in the $\vec{\omega}$ rheumatic fever group with decreased serum haptoglobins.

One of our patients developed acute haemolytic i anaemia a few days after the insertion of a mitral $\dot{\sigma}$ valve prosthesis. We observed 23 patients after the replacement of a damaged aortic valve by a $\stackrel{\infty}{\infty}$ prosthesis or homograft. Poikilocytosis occurred in 음 one of these, but none developed overt haemolytic $\vec{z}$ anaemia. This is in contrast to the experience of $z$

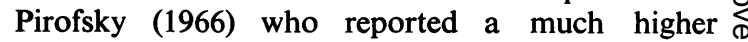
incidence of haemolytic anaemia following the $\frac{1}{3}$ insertion of an aortic than a mitral valve prosthesis, $\mathbb{\Phi}$ the incidence being $10 \%$ after aortic valve surgery.

The cause of the haemolysis in our patient with a mitral valve prosthesis is obscure. There were no signs of a mechanical defect, and the anaemia and anisopoikilocytosis recovered without further surgery. The reason for the transient appearance of the anti-Kell antibody is not clear, but it is possible that the patient, who was Kell-negative, received Kell-positive blood during both a previous and the present operation, thereby stimulating antibody production. The patient's own red blood cells could not have been damaged by the anti-Kell antibody, and as it is unlikely that more than two of the 10 bottles of transfused blood were Kell-positive, this antibody was probably not responsible for such a severe degree of anaemia. The Coombs test was negative at the onset of the haemolysis, 17 days later the test was quite strongly positive, and after a further eight days it was negative. Pirofsky et al. (1965) described six similar cases and considered that there might be an autoimmune mechanism. They suggested that mechanical trauma, insufficient $\mathrm{N}$ in itself to destroy the red blood cells, might modify the surface antigen by damage to the cell membrane and thus initiate antibody production. However, a positive direct Coombs test does not necessarily mean that the globulin coating the erythrocytes is an antibody, and non-antibody globulin may become $\mathbb{D}$ attached to abnormal cells as, for instance, in megaloblastic anaemia (Forshaw and Harwood, 1965).

We wish to thank the physicians at Sefton General $\stackrel{\mathbb{D}}{\stackrel{2}{2}}$ Hospital, who have permitted us to publish details of 
their patients, and Mr. P. J. Molloy and Dr. J. A. Campbell for giving us details of one patient during the time he was in Broadgreen Hospital.

\section{REFERENCES}

Brain, M. C., Dacie, J. V., and Hourihane, D. O'B. (1962). Brit. J. Haemat., 8, 358.

Brodeur, M. T. H., Sutherland, D. W., Koler, R. D., Starr, A., Kimsey, J. A., and Griswold, H. E. (1965). Circulation, 32, 570.

Cooley, M. H. (1966). Arch. intern. Med., 118, 486.

Dacie, J. V., and Lewis, S. M. (1963). Practical Haematology, 3rd ed. Churchill, London.

Forshaw, J., and Harwood, L. (1965). J. clin. Path., 18, 119.

(1966). Arch. intern. Med, 117, 203.

Marsh, G. W. (1964). Lancet, 2, 986.

Miller, D. S., Mengel, C. E., Kremer, W. B., Gutterman, J., and Senningen, R. (1966). Ibid., 65, 210.

Murray, R. F., Jr., Robinson, J. C., Dublin, T. D., Pitt, E. L., and Visnich, S. (1966). Brit. med. J., 1, 762.

Neale, F. C., Aber, G. M., and Northam, B. E. (1958). J. clin. Path., 11, 206.

Pirofsky, B., Sutherland, D. W., Starr, A., and Griswold, H. E. (1965). New Engl. J. Med., 272, 235.

(1966). Ann. intern. Med., 65, 373.

Rose, J. C., Hufnagel, C. A., Freis, E. D., Harvey, W. P., and Partenope, E. A. (1954). J. clin. Invest., 33, 891

Sayed, H. M., Dacie, J. V., Handley, D. A., Lewis, S. M., and Clelan, W. P. (1961). Thorax, 16, 356.
Weiss, H. J. (1963). Amer. J. Med., 35, 455.

Westring, D. W. (1966). Ann. intern. Med., 65, 203.

Ziperovich, S., and Paley, H. W. (1966). Ibid., 65, 342.

\section{ADDENDUM}

Since this paper was completed we have observed another patient, a woman aged 37, who developed haemolytic anaemia after the insertion of aortic and mitral valve prostheses. The haemoglobin level fell to $8 \cdot 3 \mathrm{~g}$. per $100 \mathrm{ml}$., the reticulocytes rose to $14 \%$, and the blood film showed polychromasia and poikilocytosis with schistocytes and burr cells. The serum bilirubin was $1.9 \mathrm{mg}$. per $100 \mathrm{ml}$., and there was haemosiderin and an excess of urobilinogen in the urine. There was a transiently positive direct Coombs test up to a titre of $1: 16$, but the reaction was only weak. There was no clinical evidence to suggest that either prosthesis had developed a mechanical defect.

She has been treated with Prednisone for two months, and at the end of this period the haemoglobin was $10 \cdot 2 \mathrm{~g}$. per $100 \mathrm{ml}$., reticulocytes $3.5 \%$, serum bilirubin $0.5 \mathrm{mg}$. per $100 \mathrm{ml}$., and there was no excess urobilinogen in the urine. 